\title{
ВПЛИВ ІМУННОЇ КАСТРАЦІЇ СВИНОК ТА ЇХ ПЕРЕДЗАБІЙНОЇ ЖИВОЇ МАСИ НА ЯКІСНІ ПОКАЗНИКИ М'ЯСА
}

\author{
Андрєєва Діана Миколаївна \\ аспірант спеціальності 204 «ТВППТТ» \\ Миколаївський національний аграрний університет \\ ORCID: 0000-0003-4572-0856 \\ Email: andreevasvk@gmail.com
}

\begin{abstract}
В статті порівняно фрізико-хімічні показники та хімічний склад найдовшого м'язу спини (m. longissimus dorsi) в імунокастрованих та некастрованих свинок отриманих від помісних свиноматок ірландського ландраса та ірландського йоркшира і кнурів синтетичної лінії Мaxgro за їх забою в 110 кг та 130 кг. Встановлено, що за фізико-хімічними показниками м'яса імунокастрованих та некастрованих свинок обох досліджуваних вагових категорій суттєвих розбіжностей не було. Проте спостерігалась тенденція до збільшення у м'ясі імунокастрованих тварин відсотку вільної вологи через 48 годин та на 6-ту добу після забою, вологоутримуючої здатності, вмісту зв'язаної вологи у \% до загальної вологи та мармуровості порівняно зі своїми некастрованими аналогами. Водночас за показниками колірності та електропровідності через 48 годин та на 6-ту добу після забою мали перевагу над своїми аналогами некастровані свинки живою передзабійною масою 110 ке, тоді як, у тварин за вагової категорії 130 кг спостерігалась зворотна тенденція за досліджуваними показниками. 3 аналізу показнику активної кислотності найдовшого м'язу спини встановлено що дозрівання м'язової тканини імунокастрованих свинок за обох вагових категорій було дещо повільнішим в порівнянні з некастрованими свинками. 3 підвищенням передзабійної живої маси з 110 до 130 кг м'ясо, як імунокастрованих так і некастрованих свинок набуває кислішої реакиії. За хімічним складом найдовшого м'язу спини значних відмінностей між імунокастрованими та некастрованими тваринами за різної їх передзабійної живої маси не встановлено, та всі досліджувані показники знаходились в межах норми для м'яса категорії NORM. За показникам масової частки вологи та золи спостерігалась тенденція до збільшення їх у м'ясі імунокастрованих свинок з передзабійною живою масою 110 ке на 0,15\% та на 0,02\%, а з передзабійною живою масою 130 кг відповідно на 0,20\% та на 0,01\% порівняно зі своїми некастрованими аналогами. Встановлено більшу масову частку білку була у м'ясі некастованих свинок за передзабійної живої маси як 110 так 130 ка відповідно на 0,21\% та 0,18\% порівняно з імунокастрованими тваринами таких же самих вагових категорій. Масова частка жиру у м'язовій тканині імунокастрованих свинок за живої маси 110 ка була більша на 0,04\% в порівнянні з м'ясом їх некастрованих аналогів. Водночас за вагової категорії 130 кг у найдовщому м'язі спини імунокастрованих свинок масова частка жиру виявилось меншою на 0,03\% порівняно з некастрованими тваринами аналогічної вагової категорії. За результатами двофракторного дисперсійного аналізу дія фактору передзабійної живої маси тварин, типу кастраиії та їх взаємодія не мала статистично вірогідного впливу на більшість досліджуваних фрізико-хімічних показників які у більшості випадків залежали від неврахованих фракторів. Отримані результати досліджень засвідчили, що застосування імунної кастрації для свинок не має негативного впливу на якісні показники м'яса свинок.
\end{abstract}

Ключові слова: свинка, імунна кастрація, передзабійна жива маса, якість м'яса, хімічні показники, вільна волога, вологоутримуюча здатність, активна кислотність, електропровідність.

DOI: https://doi.org/10.32845/bsnau.lvst.2021.3.6

На думку І.Б. Баньковської [8] О.М. Булатовича [11], Ю.Г. Бургу та [12] посилена селекція на м'ясність та скороспілість свиней привела до створення генотипів які мають високі прирости та більший вихід м'яса в тушах. Водночас паралельно з цим виникає проблема їх якості туш [13]. Тому необхідно не лише нарощувати відсоток м'яса в тушах свиней, а й фіксувати якісні показники, які мають вирішальну роль під час виготовлення м'ясних виробів на переробних підприємствах [10, 21, 22, 9]. Водночас інші вчені [19, 20, 1, 23] наголошують на тому, що не завжди висока м'ясність свиней супроводжується погіршенням якості м'яса.

В процесі виробництва продукції свинарства на формування показників м'яса впливає цілий ряд, як онтогенетичних, так і паратипічних фракторів. Виробники свинини для підвищення рентабельності виробництва, почали стрімко впроваджувати в технологію виробництва свинарства альтернативу хірургічній кастрації - імунну кастрацію свиней. Даний метод кастрації $є$ більш гуманним по відношенню до тварин, а також потребує менших затрат трудових ресурсів. Проте така зміна технології може вплинути безпосередньо

на якість м'яса. Тому в даній статті було поставлено завдання дослідити вплив імунної кастрації свинок на якісні показники їх м'яса.

І.Б. Баньковська [4] стверджує, що під поняттям «якість м'яса» розуміють широкий спектр його властивостей, що характеризують харчову і біологічну цінність продукту, а також органолептичні, структурно-механічні, функціональнотехнологічні, гігієнічні, токсикологічні та інші його характеристики і властивості. За даними Л. В Антипова [1] м'ясо свиней перетравлюється організмом людини на $95 \%$, а калорійність 1 кг свинини середньої вгодованості складає 8100 ккал, в той час як яловичини та баранини середньої вгодованості - відповідно 1500-1550 та 1200-1300 ккал. Крім того, за матеріалами його публікацій у свинині порівняно з яловичиною та бараниною, міститься менше води і більше сухого залишку.

В системі оцінки якості м'яса свиней за повідомленнями І. Б. Баньковської [7] визначають чотири групи показників: - ознаки харчової цінності (вміст протеїну і його компонентів, внутрішньом'язового жиру, вітамінів, вуглеводів, макро- та мікроелементів); - органолептичні властивості

Вісник Сумського національного аграрного університету 
(зовнішній вигляд, колір, мармуровість, структура, смак, запах, консистенція, ніжність, соковитість);- санітарногігієнічні (показники безпеки - рівень патогенної мікрофрлори, токсинів, солей важких металів, нітритів, пестицидів, антибіотиків, гормонів); - технологічні (вологоутримуюча здатність, ніжність, інтенсивність забарвлення, активна кислотність (рН), втрати при терміччній обробці, електропровідність).

Хімічний склад м'язової тканини свиней в середньому містить: вологи (73-77\%), протеїну (18-21\%), жиру (1-5\%), екстрактивних речовин (1,7-2\% азотисті, 0,9-1,2\% безазотисті), мінеральних речовин (0,8-1\%) [2]. Оптимальний показник вологоутримуючої здатності м'яса або кількість води, що зв'язана з 1г протеїну становить 2,5 г [4].

Харчова цінність м'яса на думку И. Б. Баньковскої [5] зумовлюється наявністю у складі свинини внутрішньом'язового жиру який надає їй високої калорійності, ніжності, сприяє появі певного аромату. Протеїновий комплекс за даними Г. Бажова, Л. Бахиревої [2] складається приблизно з 20\%, міогену, 20 \% глобуліну X, 40 \%, міозину та12 \% актину від загальної маси всіх протеїнів. Вуглеводи в м'ясі свиней представлені переважно глікогеном. Кількість вуглеводів у дозрілому м'ясі становить близько 1,0-1,5 \%. Їх роль здебільшого пов'язана з участю в автолітичних процесах: зміни консистенції, величини рН, ніжності, формування смаку, аромату, тобто вуглеводи опосередковано впливають на якість м'яса свиней і його біологічну цінність [6].

Окрім рН та кольору м'язової тканини популярним та надійним показником для ідентиффікації вад м'яса вважається електропровідність. Питома електропровідність (LF) - це здатність речовини проводити електричний струм у розчині, що знаходиться між електродами . У системі Сl вона має одиниці виміру Ом-1м-1 або Сіменс'м-1 (мСм/см). У найдовшому м'язі спини низький рівень LF24 $\leq 5,00$ мСм/см - характерний для DFD - свинини (Dark - темне, Firm - жорстке, Dry - сухе). LF24 в діапазоні 5,00-6,99 мСм/см - електропровідністьмяса в нормі, високий показник LF24 $27,00 \mathrm{mCM} / \mathrm{cm}$ характерний для PSE свинини - (Pale - блідне, Soft - дрябле, Exudative - водянисте). Величина електропровідності збільшується обернено пропорційно значенню $\mathrm{pH}$ і є гарним індикатором м'яса з PSE вадою. При рH24 $\leq 5,6$ електропровідність переважно - $\geq 8,0$ мСм/см, а показник інтенсивності забарвлення характеризується більш світлим відтінком, ніж нормальне м'ясо. Електропровідність бажано вимірювати безпосередньо в тушах. Відокремлення м'язів призводить до підвищеного вивільнення в міжклітинний простір вологи і збільшення рівня LF майже у 2 рази [14]

Оптимальний рівень основних параметрів якості свинини на думку Н. Ф.Бамбуляка, С. Г. Вылкова, Р. И. Ройбу [3] - вологоутримуюча здатність - 53-65 \%; pH24 5,6-6,2, pH48 - 5,2-5,8; електропровідність міжреберних м'язів в межах 1,7-2,1 мСм/см., За їхніми спостереженями час вимірювання впливає на рівень LF з силою п2 $=21,4 \%$, $\mathrm{p} \leq 0,001$.

Як повідомляють C.Pauly, P. Spring, J.V. O'Doherty, S. Ampuero Kragten, G. Beе [34] імунокастровані свині мають більший генетичний потенціал для засвоєння білків кормів та краще їх використання, ніж хірургічні кастрати. G.M Cronin з співавторами [24] встановили, що імунологічна кастрація відповідає вимогам виробників і за її використання вдається уникнути прояву запаху кнура, хоч характеристики м'яса можуть відрізнятися між кнурами та імунокастратами. За повідомленнями K. Lundstrom., K. Matthews.R., J.E. Haugen [31] є відмінності в показниках вартості туші і якості м'яса були у імунокастрованих тварин. Отримані результати, як стверджують D.N.D'Souza, B.P.Mullan [25] суттєво відрізняються за використання тварин різних порід та гібридних комбінацій, стратегії годгодвлі (необмежена, або обмежена). Також за повідомленнями M.Skrlep з співавторами [36] на якість м'яса суттєво впливають час другої вакцинації (за 4 і більше тижнів до забою) та спосіб утримання (груповий або індивідуальний).

M.Gispert та ін. [32] досліджуючи вплив імунної кастрації на якість м'яса та туші порівняно з м'ясом нативних самок хірургічно кастрованих та некастровах кнурців, виявили, що найбільшу кількість внутрішньом'язового жиру мали хірургічно кастровані кнурці, проте за складом він нічим не відрізнявся від некастрованих свинок та кнурців а також імунокастрованих кнурців.

N. Andreo та ін [33] встановили що імунокастровані тварини мали більш високий рівень рН починаючи 38 години, нижчу кольоровість м'язової тканини, менший діаметр м'язових волокон та та більший прошарок жиру між ними, порівняно 3 хірургічно кастрованих тварин. Водночас R. Eugeniusz [26] в своїх дослідженнях дійшов до висновків, що тип кастрації не впливає на кислотність м'яса, але має значний вплив на вміст вільної вологи та ніжність м'яса. За його повідомленнями, колір м'яса у тушах імунокастрованих кнурців був менш насиченим, в ньому спостерігалась менша кількість жиру ( $\mathrm{P} \leq 0,05$ та найнижчим вмістом білка ( $\mathrm{P} \leq$ 0,05). Він стверджує, що м'ясо імунокастрованих самців було більш ніжним та мало більш сприятливі параметри текстури м'язів.

Враховуючи недостатній рівень вивчення питання впливу імунологічної кастрації свинок в умовах промислової технології виробництва свинини за використання інтенсивних генотипів свиней в Україні, актуальним є завдання дослідити вплив імунної кастрація свинок на якість м'яса.

Метою досліджень було оцінити вплив імунної кастрації свинок на якісні показники м'яса, та провести порівняльну характеристику фізико-хімічних властивостей та хімічного складу найдовшого м'язу спини імунокастрованих та некастрованих свинок за різної передзабійної живої маси.

Матеріали та методи досліджень. Для вивчення якісних показників м'яса імунокастрованих свинок проведено дослідження в умовах цеху відгодівлі № 3 ТОВ «НВП «Глобинського свинокомплексу» та Глобинського м'ясокомбінату. У віці 70 діб було поставлено на відгодівлю та сфрормовано методом груп аналогів дві групи свинок отриманих від помісних свиноматок ірландського ландраса та ірландського йоркшира і кнурів синтетичної лінії Maxgro, по 220 голів в кожній.

Для обох груп були створенні однакові умови утримання (в групових станках по 55 голів з нормою площі 0,75 м² в розрахунку на одну голову, з повністю щілинною підлогою). Годівля тварин проводилась рідкими кормосумішами, приготування та роздача яких здійснювалась за допомогою системи рідкої годівлі VEDA австрійського виробництва. Всі лікувальні та профілактичні заходи були ідентичні для обох груп за винятком проведення тваринам дослідної групи імунної кастрації на 42-й день відгодівлі та повторної їх ревакцинації на 78-й день відгодівлі.

При постановці свинки обох груп були індивідуально Вісник Сумського національного аграрного університету 
зважені та ідентифіковані різнокольоровими бирками. Під час досліду щоденно проводився облік з"їдених кормів на окремий станок та загалом по групах. Також враховувався загальний стан тварин, та фріксування у відповідні журнали тварин, що вибули з зазначенням причини вибуття та кінцевої живої маси.

Напередодні закінчення відгодівлі свинок дослідної та контрольної груп були індивідуально зважені. Визначену кінцеву живу масу вказували на спині тварини за допомогою маркер спрею. Після чого на основі цих даних було відібрано $з$ кожної групи по 20 голів свинок (10 голів з живою масою

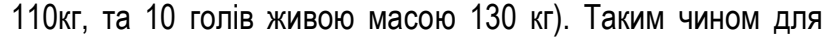
контрольного забою було сформовано 4 групи тварин по 10 голів за різної передзабійної живої маси.

Перед відправкою на забій кожній свинці провели додаткове мічення за допомогою татуювання на задньому окосту, для їх подальшої ідентифікації під час забою. В цей же день тварини всіх груп були завантаженні в окремі відсіки спеціального автомобіля та перевезені до Глобинського м'ясокомбінату, де після 24 - годинної голодної витримки здійснили їх контрольний забій за загальноприйнятою методикою. Після забою напівтуші охолоджувались 24 години в холодильній камері за температури від 2 до $4 \mathrm{C}^{\circ}$, після чого було проведено їх обвалювання. В процесі обвалювання 3 обох напівтуш були відібрані та ідентифіковані зразки найдовшого м'яза спини на рівні 9-12 грудного хребця, та відправлені до сертифікованої лабораторії Глобинського м'ясокомбінату, де і проводились подальше визначення якості м'яса імунокастрованих та некастрованих свинок відповідно до ISO 3100-1 [29].

Колір та мармуровість м'яса визначали візуально за допомогою шкали Minolta L. Для цього експертною групою 3 п'яти осіб за використання вище вказаної шкали, на яку нанесенні пігменти та зображення, що точно відображали колір та структуру поверхні найдовшого м'яза спини було візуально оцінено по п'ятибальній шкалі інтенсивність забарвлення (від світлого до червоного) та мармуровість (від кількості, щільності та розміру прожилків з'єднувальних тканин) м'язової тканини досліджуваних свиней.

Активну кислотність м'яса визначали одразу після забою $\left(\mathrm{pH}_{0}\right)$, через 24 години $\left(\mathrm{pH}_{24}\right)$, через 48 годин $\left(\mathrm{pH}_{48}\right)$, та на 6 добу ( $\mathrm{pH}_{6 д}$ ) за допомогою pH-метру Testo 205 (AG, Germani). Перед використанням рН-метру здійснили його калібрування буферними розчинами за завчасно визначеними рН відповідно до ISO 2917:1999 [28].

Електропровідність м'язової тканини вимірювали спеціальним приладом LF-Star CPU-Pistole (Німеччина), робоча поверхня якого складається 3 двох паралельних електродів високоякісної сталі, довжиною 50 мм та інтервалом між ними 25 мм.

Вільну вологу м'яса, визначали через 48 годин та на 6 добу після забою тварин, за різницею маси м'яса в вакуумній упаковці, маси самої упаковки та маси м'яса, з наступним перерахунком цього показника у відсотки.

Вологоутримуючу здатність визначали за допомогою прес-методу R. Grau, R. Hamm [27], при цьому вміст зв'язаної вологи у \% до маси м'яса розраховували за формулою

$$
\mathrm{X} 1=\frac{(\mathrm{A}-8,4 \times \mathrm{b}) \times 100}{\mathrm{M}_{0}}
$$

Вісник Сумського національного аграрного університету
Вміст зв'язаної вологи у \% до загальної вологи розраховували за формулою

$$
X 2=\frac{(A-8,4 \times 5) \times 100}{A}
$$

де:

А - загальний вміст вологи в наважці (мг);

Б - площа вологого п'ятна $\left(\mathrm{cm}^{2}\right)$;

М0 - маса наважки м'яса;

8,4 - коефіцієнт перерахунку $1 \mathrm{~cm}^{2}$ площі вологого п'ятна в 1 мг води.

Хімічний аналіз м'яса з визначенням масової частки вологи (\%), білку (\%), жиру (\%) та золи (\%) проводили за загальноприйнятими методиками, описаними [18] та нормативними документами $[15,16,17$

Масову частку вологи \% розраховували за формулою S. Severiano [35]:

$$
X=\frac{m_{1}-m_{2}}{m} \times 100
$$

де:

Х3 - вміст вологи, \%;

m1- маса наважки з бюксою до висушування, г;

$\mathrm{m} 2$ - маса наважки з бюксою після висушування, г;

m- маса бюкси.

Для цього у м'ясі, висушеному до повітяно-сухого стану при температурі $60-65^{\circ} \mathrm{C}$, визначали: вміст загальної вологи - за різницею маси проб до та після висушування в сушильній шафі при температурі $100-105^{\circ} \mathrm{C}$. Масову частку жиру визначали екстрагуванням петролейним ефріром за методом Сокслета, а масову частку золи - спалюванням у муфельній печі при температурі $450{ }^{\circ} \mathrm{C}$. Масова частка білку, у \% була визначена згідно ISO 5983-1:2005 [30] за використанням системи дайджесту K-437 та методики пробовідбору Kjeldahl.

Матеріали експериментальних досліджень опрацьовано за допомогою методів варіаційної статистики [18]. Також, з метою визначення сили впливу передзабійної живої маси та типу кастрації свинок на якісні показники м'яса було проведено двофакторний дисперсійний аналіз.

Результати досліджень. За результатами досліджень (табл. 1) встановленні відмінності за фрізико-хімічними показниками найдовшого м'язу спини імунокастрованих та некастрованих свинок за різної передзабійної живої маси.

Так, в м'ясі імунокастованих свинок з живою масою 110 та 130 кг спостерігалось тенденція до незначного перевищення масової частки вільної вологи через 48 годин після забою на 0,65\% та 0,16 \% порівняно з м'ясом некастрованих свинок аналогічних вагових категорій. В той час масова частка вільної вологи на 6 добу після забою мала зворотну тенденцію, тобто м'ясо некастрованих свинок живою масою 110 та 130 кг мало більшу частку вільної вологи на 0,23\% та на 0,10\% ніж м'ясю їх імунокастрованих аналогів.

М'язова тканина імунокастрованих тварин забитих за живої маси 110 та 130 кг мала тенденцію до збільшення вологоутримуючої здатності на 1,03\% та на 1,08\% в порівнянні з м'ясом некастрованих свинок таких же вагових категорій. За вмістом зв'язаної вологи у \% до загальної вологи, виявлено тенденцію до її підвищення у м'ясі імунокастрованих свинок за обох вагових категорій. Так за показником вмісту зв'язаної вологи у \% до загальної вологи, м'ясо імунокастрованих свинок з передзабійною живою масою 110 та 130 кг перевищувало м'ясо некастрованих аналогів відповідно на $0,67 \%$ та на $1,23 \%$. Таким чином м'ясо імунокастро- 
ваних свинок різних вагових кондицій краще утримує вологу, саме тому воно є більш соковитіше.

За показником колірністі м'язової тканини у балах за шкалою Minolta L було встановлено, що м'ясо тварин дослідної групи за живої маси 110 кг мало на 0,05 менше балів порівняно з аналогами контрольної групи. М'ясо ж імунокастрованих свинок за живої маси 130 кг навпаки мало більше на 0,34 бали $(p<0,01)$ показник колірності ніж м'язова тканина некастрованих свинок такої самої передзабійної живої маси. Мармуровість виявилась кращою у м'ясі імунокастрованих свинок обох вагових категорій порівняно з м'ясом некастрованих свинок. Так м'ясо імунокастрованих тварин живою масою 110 кг за мармуровістю перевищувало показники своїх некастрованих аналогів на 0,08 балів, в той час м'язова тканина імунокастрованих свинок живою масою 130 кг мала перевищення на 0,22 бали в порівнянні 3 м'ясом своїх некастрованих аналогів.

Фізико-хімічні показники найдовшого м'язу спини (m. longissimus dorsi)

Таблиця 1

імунокастрованих та некастрованих свинок за різної передзабійної живої маси,

$(M \pm m)(n=10)$

\begin{tabular}{|l|c|c|c|c|}
\hline \multirow{2}{*}{ Показники } & \multicolumn{2}{c|}{$\begin{array}{c}\text { Імунокастровані свинки } \\
\text { (дослідна група) }\end{array}$} & \multicolumn{2}{c|}{$\begin{array}{c}\text { Некастровані свинки } \\
\text { (контрольна група) }\end{array}$} \\
\cline { 2 - 5 } & 110 кг & 130 кг & 110 кг & 130 кг \\
\hline Масова частка вільної вологи 48 год., \% & $2,32 \pm 0,613$ & $2,62 \pm 0,392$ & $1,67 \pm 0,165$ & $2,46 \pm 0,405$ \\
\hline Масова частка вільної вологи на 6 добу, \% & $3,15 \pm 0,325$ & $3,41 \pm 0,378$ & $3,38 \pm 0,403$ & $3,51 \pm 0,442$ \\
\hline Вологоутримуюча здатність, \% & $62,26 \pm 0,924$ & $61,94 \pm 0,540$ & $61,23 \pm 0,840$ & $60,86 \pm 0,581$ \\
\hline $\begin{array}{l}\text { Вміст зв'язаної вологи у \% до загальної } \\
\text { вологи }\end{array}$ & $83,30 \pm 1,243$ & $83,50 \pm 0,763$ & $82,63 \pm 0,980$ & $82,27 \pm 0,855$ \\
\hline Колірність, бали & & & & \\
\hline Мармуровість, бали & $2,10 \pm 0,061$ & $2,43 \pm 0,077$ & $2,15 \pm 0,136$ & $2,09 \pm 0,104$ ** \\
\hline Електропровідність 48 год, мСм/см & $2,08 \pm 0,215$ & $2,48 \pm 0,131$ & $2,00 \pm 0,142$ & $2,26 \pm 0,294$ \\
\hline Електропровідність на 6 добу, мСм/см & $12,13 \pm 0,325$ & $12,49 \pm 0,379$ & $12,51 \pm 0,299$ & $11,91 \pm 0,422$ \\
\hline
\end{tabular}

Примітка: ** $(p<0,01)$

Електропровідність м'яса тварин дослідної групи вагової категорії 110 кг через 48 годин після забою була меншою на 0,38 мСм/см або на 3,13\% ніж у м'ясі тварин контрольної групи. У м'ясі імунокастрованих свинок живою масою 130 кг спостерігалась зворотна тенденція, так показник електропровідності м'яса зазначених вище тварин через 48 годин після забою було вищим на 0,58 мСм/см або на 4,64\% ніж у м'ясі некастованих свинок живою масою 130 кг.

Повторивши визначення електропровідності м'яса тварин дослідних та контрольних груп на 6 добу після забою встановлено схожу тенденцію як і після 48-ми годин після забою. Проте різниця склала для обох вагових категорій по

\section{0,04 См/м або 0,31\%.}

Одним з найважливіших показників якості м'яса є його кислотність, яка вказує на швидкість процесів його дозрівання. Як видно з рис.1 та 2 динаміка змін активної кислотності найдовшого м'язу спини імунокастрованих та некастрованих свинок за передзабійної живої маси 110 та 130 кг дуже схожа, та в цілому знаходиться в межах норми. Так одразу після забою вона становила 6,21-6,27 одиниць, через 24 години після забою - 5,77-5,97 одиниць, через 48 годин - 5,47-5,57 одиниць та на 6 добу після забою - 5,515,58 одиниць.

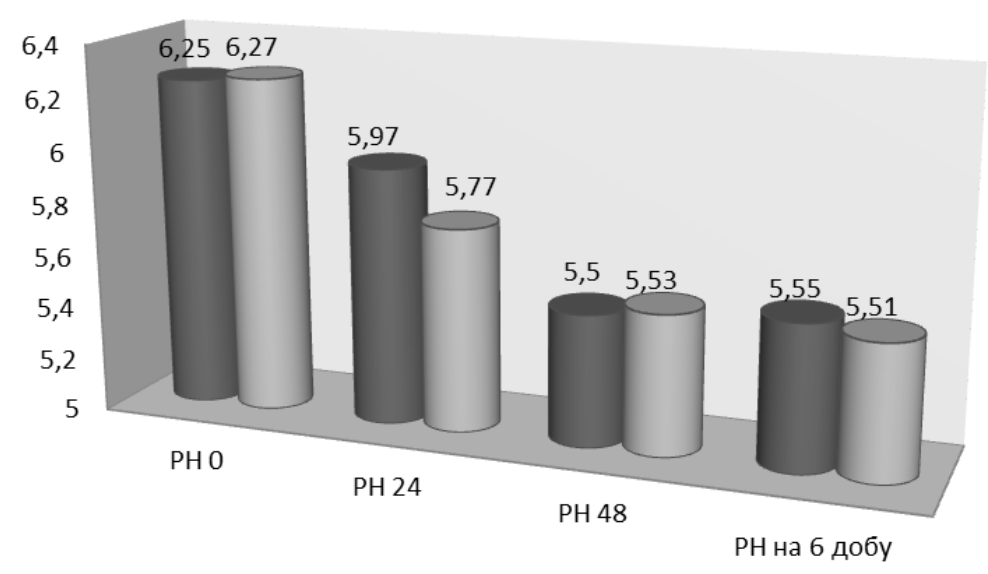

— Імунокастровані свинки живою масою 110 кг

口 Некастровані свинки живою вагою 110 кг

Рис. 1 Динаміка змін активної кислотності найдовшого м'язу ( m. longissimus dorsi) спини імунокастрованих та некастрованих свинок за передзабійної живої маси 110 кг

В нормі м'язова тканина в процесі дозрівання набу- властивості та забезпечується довше зберігання. 3 рис. 1 та ває кислішої реакції, тим самим покращуються його смакові

2 видно, що активна кислотність найдовшого м'язу спини як 
імунокасторованих так і некастрованих свинок за різних вагових категорій в процесі дозрівання набуває кислішої реакції, проте необхідно зазначити, що процес дозрівання м'язової тканини і імунокастрованих свинок обох вагових категорій був дещо повільніший ніж у некастрованих свинок.

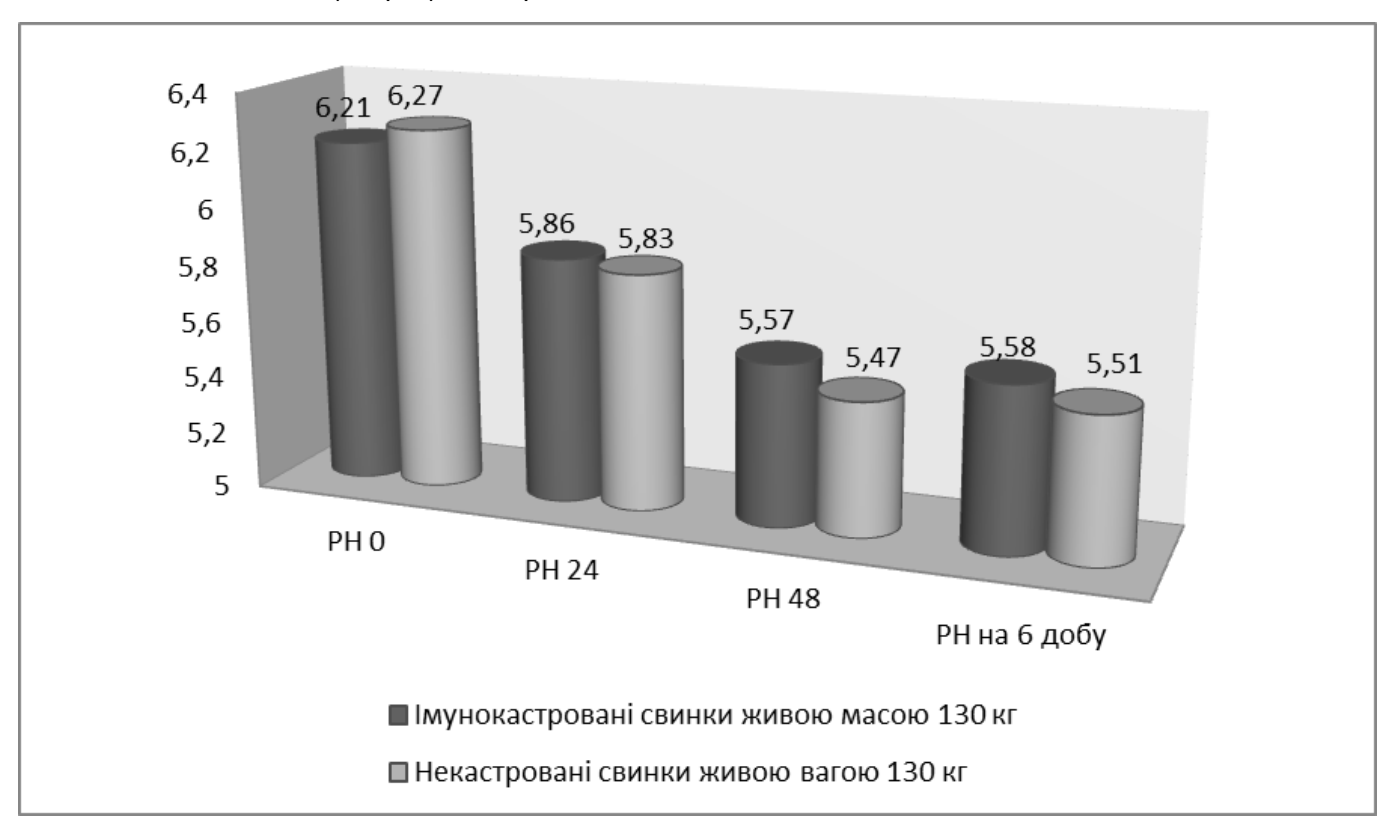

Рис. 2 Динаміка змін активної кислотності найдовшого м'язу ( m. longissimus dorsi) спини імунокастрованих та некастрованих свинок за передзабійної живої маси 130 кг

А незначне підвищення активної кислотності найдовшого м'язу спини на 6 добу на, нашу думку, зумовлене збільшенням кількості вільної вологи в процесі заморожуванням та розморожуванням зразків.

Поряд з основними фізико-хімічними властивостями на якість м'яса та його технологічні властивості має його хімічний склад. За даними наших досліджень наведеними в табл. 2, хімічний склад найдовшого м'язу спини значних відмінностей між тваринами дослідних та контрольних груп за різної передзабійної живої маси не мав. Всі показники хімічного складу м'язової тканини знаходились в межах норми та схожі з даними літературниз джерел [3]. Варто зазначити, що за такими показниками як, масова частка вологи та золи спостерігалась тенденція до збільшення їх у м'ясі імунокастрованих свинок з передзабійною живою масою 110 кг на 0,15\% та на 0,02\%, тоді як, у м'ясі імунокастрованих тварин передзабійною живою масою 130 кг таке збільшення становило відповідно на 0,20\% та на 0,01\% порівняно зі своїми некастрованими аналогами.

\section{Хімічний склад найдовшого м'язу спини ( $\mathrm{m}$. longissimus dorsi) імунокастрованих та некастрованих свинок за різної передзабійної живої маси,}

$(M \pm m)(n=10)$

\begin{tabular}{|l|c|c|c|c|}
\hline \multirow{2}{*}{ Показники } & \multicolumn{2}{|c|}{$\begin{array}{c}\text { Імунокастровані свинки } \\
\text { (дослідна група) }\end{array}$} & \multicolumn{2}{c|}{$\begin{array}{c}\text { Некастровані свинки } \\
\text { (контрольна група) }\end{array}$} \\
\cline { 2 - 5 } & 110 кг & $130 \mathrm{\kappa г}$ & 110 кг & 130 кг \\
\hline Масова частка вологи, \% & $74,23 \pm 0,235$ & $74,19 \pm 0,218$ & $74,08 \pm 0,202$ & $73,99 \pm 0,251$ \\
\hline Масова частка білку, \% & $22,63 \pm 0,159$ & $22,48 \pm 0,131$ & $22,84 \pm 0,175$ & $22,66 \pm 0,146$ \\
\hline Масова частка жиру, \% & $2,01 \pm 0,198$ & $2,17 \pm 0,171$ & $1,97 \pm 0,215$ & $2,20 \pm 0,191$ \\
\hline Масова частка золи, \% & $1,13 \pm 0,023$ & $1,16 \pm 0,037$ & $1,11 \pm 0,032$ & $1,15 \pm 0,029$ \\
\hline
\end{tabular}

В найдовшому м'язі спини імунокастрованих тварин вагових категорій 110 та 130 кг порівняно з некастрованими свинками таких же вагових категорій масова частка білку була меншою на $0,21 \%$ та $0,18 \%$. Масова частка жиру у м'язовій тканині імунокастрованих свинок за живої маси 110 кг була більша на 0,04\% ніж у м'ясі некастрованих аналогів. Водночас у найдовшому м'язі спини імунокастрованих свинок вагової категорії 130 кг масова частка жиру виявилось менше на 0,03\% ніж у м'язовій тканині некастрованих тварин такої ж самої вагової категорії.

Методом двофракторного дисперсійного аналізу визначено силу впливу передзабійної маси та кастрації тварин на їх фрізико-хімічні властивості. Так дослідженнями встановлено, що на такі показники як відсоток вільної вологи в м'ясі через 48 годин та на 6-ту добу після забою, вологоутримуюча здатність у \%, вміст зв'язаної вологи у \% до загальної вологи, мармуровість, електропровідність через 48 годин та на 6-ту добу після забою, $\mathrm{pH}_{0}$ та на $\mathrm{pH}_{24}$ передзабійна жива маса тварин, кастрація та взаємодія двох факторів не мали вірогідного впливу на, а невраховані фактори змінювали відповідні показники з силою 91,89\%, 98,63\%, $93,61 \%, 96,97 \%, 91,15 \%, 94,42 \%, 95,97 \%, 99,17 \%, 93,66 \%$.

Результат впливу взаємодії двох фракторів на колір-

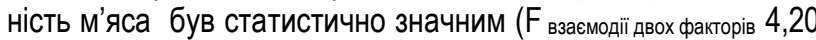

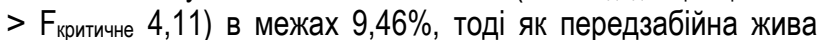
маса та фрактор кастрації не мали статистично вірогідного впливу на досліджуваний показник. Невраховані фактори змінювали показник колірності з силою 80,99\%. 
Аналіз впливу досліджуваних фракторів на зміну показника $\mathrm{pH}_{48}$ виявило статистично не достовірний вплив передзабійної живої маси та типу кастрації. Статистично вірогідними виявилися вплив факторів кастрації та його взаємодія з передзабійною живою масою $\left(\mathrm{F}_{\text {взаємодія двох факторів }}\right.$ $\left.5,41>F_{\text {критичне }} 4,11\right)$ в межах $12,46 \%$. Невраховані фрактори вплинули на зміни досліджуваного показника 82,81\%.

В той час двофакторним аналізом встановлено достовірний вплив фактору типу кастрації на $\mathrm{pH}_{6 д о б а ~}\left(\mathrm{~F}_{\text {тип кастрації }}\right.$ $\left.4,73>F_{\text {критичне }} 4,11\right)$ з силою $11,43 \%$ та не виявлено вірогідного впливу факторів перездабійної живої маси тварин і взаємодії факторів передзабійної живої маси та типу кастрації на досліджуваний показник за сили впливу 87,09\% неврахованих фракторів на даний показник .

Результати наших досліджень стосовно більш вищого ураження $\mathrm{pH}$ у м'ясі імунокастрованих свинок співпадають з результатами досліджень N. Andreo та ін [33], та з дослідженями Eugeniusz R.Grela та ін [26], які встановили що м'ясо імунокастрованих кнурців мало більший вміст вільної вологи. Після обробки показників якості м'яса двофакторним дисперсійним аналізом, наші думки збігаються 3 дослідниками G.M.Cronin та ін [24], K. Lundstrom та ін.[31], D.N., D'Souza [25], M. Skrlep [36], оскільки сила впливу неврахованих факторів за всіх показників мала більший відсоток порівняно $з$ живою передзабійною вагою та імунною кастрацією.

Висновки. 1.Застосування імунної кастрації для свинок не несе в собі негативного впливу на фізико-хімічні властивості та хімічний склад найдовшого м'язу спини.
2. За фрізико-хімічними показниками м'яса: відсоток вільної вологи в м'ясі через 48 годин та на 6-ту добу після забою, вологоутримуюча здатність у \%, вміст зв'язаної вологи у \% до загальної вологи та мармуровість спостерігалась тенденція до збільшення у м'ясі імунокастрованих тварин порівняно зі своїми некастрованими аналогами. Колірність та електропровідності через 48 годин та на 6-ту добу після забою мали менші значення у м'ясі імунокастрованих свинок живою передзабійною масою 110 кг порівняно зі своїми некастрованими ваговими аналогами, тоді як, у м'ясі імунокастрованих тварин за живої ваги 130 кг спостерігалась зворотна тенденція за вказаними вище показниками.

3. Активна кислотність найдовшого м'язу спини як імунокасторованих, так і некастрованих свинок за різних вагових категорій в процесі дозрівання набувають кислішої реакції, проте, сам процес дозрівання м'язової тканини та імунокастрованих свинок за обох вагових категорій був дещо повільніший ніж у некастрованих свинок.

4. За хімічними показниками найдовшого м'язу спини, які знаходились в межах норми, значних відмінностей між імунокастрованими та некастрованими тваринами різних вагових категорій не встановлено.

3. Відповідно до результатів двосракторного дисперсійного аналізу фізико-хімічні показники у більшості залежали від неврахованих факторів. Дія фактору передзабійної живої маси тварин, типу кастрації та взаємодія фракторів вагової категорії на більшість досліджуваних показників не мала статистично вірогідного впливу.

\section{Список використаної літератури:}

1. Антипова Л. В., Зубаирова Л. А., Данылив М. М. Оценка качества и безопасности мясных продуктов. Все о мясе. 2006. № 1. С. 8-9. 3. C. 6-9.

2. Бажов Г., Бахирева Л. Биотехнологические приемы повышения продуктивности свиней. Свиноводство. 2004. №

3. Бамбуляк Н. Ф., Вылков С. Г., Ройбу Р. И. Влияние дозированной двигательной активности на морфометрические показатели костей предплечья и голени свиней: Функциональные и биохимические аспекты морфологии домашних животных. Сб. науч. тр. КСХИ. Кишинев, 1990. С.41- 44.

4. Баньковская И. Б. Влияние генетических аспектов интенсивного откорма на качество свинины. Таврійський науковий вісник: зб. наук. пр. ХДАУ. Херсон: Айлант, 2008. Вип.58. Ч.2. С. 108-112.

5. Баньковская И. Б. Влияние факторов породы, живой массы и типа мышц н на качество созревания туш свиней. Современные проблемы и технологические инновации в производстве свинины в странах СНГ: материалы XX Междунар. науч.-практ. конф. по свиноводству, г. Чебоксары, 20-21 июня 2013. С. 150-156.

6. Баньковская И. Б. Экспресс-оценка созревания мышц динамического типа в тушах свиней. Конкурентоспособность и качество животноводческой продукции: сб. трудов Междунар. науч.-практ. конф., 18-19 сентября 2014 г. Жодино, 2014. C. 308-310.

7. Баньковська І. Б. Амінокислотний склад м'яса свиней різних порід та вагових кондицій. Сучасний стан та перспективи розвитку тваринництва України: зб. матеріалів Всеукр. наук.-пр. інт. конф., 8 вересня 2016 р. Херсон, 2016. С. 83-86.

8. Баньковська І.Б. Обгрунтування та розробка системи оцінки, прогнозування і оптимізації виробництва якісної продукції свинарства. Авторефр. Дис.доктора. с.-г. наук: 06.02 .01 - Миколаїв, 2017. - 43 с.

9. Бірта Г. О., Бургу Ю. Г., Флока Л. В., Морфологічний склад туш свиней різних порід. Свинарство. 2019. № 73. URL: http://nbuv.gov.ua.UJRN.svun (дата звернення 22.08.2021).

10. Бірта Г. О., Бургу Ю.Г. Товарознавство м'яса. Київ: «Центр учбової літератури», 2011. - 164 с.

11. Булатович О.М. Продуктивність та деякі біологічні особливості свиней різних генотипів . Вісник аграрної науки. 1999. № 5. С. $76-77$.

12. Бургу Ю.Г. Стрессчувствительность чистопородных и помесных поросят. Свиноводство. 2005. № 1. С. 8-9.

13. Гиря В. Н. Качество мяса у гибридных свиней. Свиноводство. 1990. Вып. 46. - С. 35-38.

14. Мясо и мясные продукты. Методы определения жира ГОСТ 23042-86. [Срок действия с 1988-01-01. Проверено 2012-07-30]. Москва : Государственный комитет СССР по стандартам. 9 с.

15. Оцінка електропровідності м'язової тканини свиней різних генотипів . І. Б. Баньковська. Свинарство: міжвід. темат. 
наук. зб. Полтава, 2010. Вип. 58. С. 40-46.

16. Павловский П. Е., Пальмин В. В. Биохимия мяса. Москва: Пищевая промышленность, 1975. С. 234 - 239.

17. Пат. № 88937, Україна, МПК А 01 К 67.02. Спосіб визначення якості м'яса туш свиней . Баньковська І. Б., Волощук В. М., Іванов В. О., заявник і власник Інститут свинарства і АПВ НААН. № и 201311251; заявл. 23.09 .2013 ; опубл. 10.04.2014; Бюл. № 7.

18. Плохинский Н. А. Руководство по биометрии для зоотехников Москва : Колос, 1969. 256 с.

19. Свечин Ю. О., Галкина Л.О. О качестве м'яса чистопородных и помесных свиней. Свиноводство. 1990. № 5. С.

26.

20. Степанов В., Федоров В., Тариченко А. Селекция свиней на мясность. Свиноводство. 1998. № 2, С. 4.

21. Шейко И.П., Епишко Т. И., Гридюшко И.Ф., Гридюшко Е.С. Использование ДНК-технологий при определении стрессовой чувствительности и продуктивности свиней. Весці Нацыянальнай акадэміі навук Беларусі, Серыя аграрных навук. 2005. № 3. С. 76-78.

22. Шипулин В. И. Качество мясного сырья и проблемы его переработки. Вестник СевКавГтУ, 2006. №1 (5). С. 15-18.

23. Auqui, S. M., Egea M., Peñaranda I., Garrido M. D., Linares, M. B. Rustic Chato Murciano pig breed: Effect of the weight on carcass and meat quality. Meat Science 2019. pp., 105-110. DOI:10.1016/j.meatsci.2019.05.022

24. Cronin G.M., Dunshea F.R., Butler K.L., McCauley I., Barnett J.L., Hemsworth P.H. The effects of immuno- and surgical castration on the behaviour and consequently growth of group-housed, male finisher pigs. Applied Animal Behaviour Science, 2003, №81, pp.111-126

25. D'Souza D.N., Mullan B.P. The effect of genotype, sex and management strategy on the eating quality of pork. Meat Science, ,20026 № 60, pp. 95-101.

26. Eugeniusz Ryszard Grela, Małgorzata Światkiewicz, Edyta Kowalczuk-Vasilev Mariusz Florek. An attempt of implemen ation of immunocastration in swine production - impact on meat physicochemical quality and boar taint compound concentration in the meat of two native pig breeds. Livestock Scienceю, 2019, №232(1). DOI:10.1016/j.livsci.2019.103905

27. Grau R, Hamm R.,. Eine einfache methode zur bestimmung der wasserbindung inmuskel. Naturwissenschaften. 1953, № 40 pp. 29-30 doi.org/10.1007/BF00595734

28. ISO 2917:1999. Meat and meat products. Measurement of pH. Reference method. Geneva, Switzerland: International Organization for Standardization, 1999.

29. ISO 3100:1, Meat and meat products. Sampling and preparation of test samples. Geneva, Switzerland. Part 1:Sampling. International Organization for Standardization, 1991.

30. ISO 5983-1:2005. Feeding stuffs - Determination of nitrogen content and calculation of crude protein content - Part 1: Kjeldahl (N x 6.25). International Organization for Standardization, Geneva, Switzerland, 2005

31. Lundstrom K., Matthews K.R., Haugen J.E. Pig meat quality from entire males. Animal, 2009, № 3, pp. 1497-1507.

32. Marina Gispert, Maria Angels Oliver, Antonio Velarde, paloma suarez Suarez. Carcass and meat quality characteristics of immunocastrated male, surgically castrated male, entire male and female pigs. Meat Science 2010, №85(4), pp. 664-700. DOI:10.1016/..meatsci.2010.03.021

33. Nayara Andreo, Ana Maria Bridi, Caio Abércio da Silva, Louise Manha Peres, Barbara de Lima Giangareli, Évelyn Rangel dos Santos, Camila Piechnicki Roge, Jéssica Gonçalves Vero, Guilherme Agostinis Ferreira. Immunocastration and its effects on carcass and meat traits of male pigs. Semina: Ciências Agrárias, 2018, vol. 39, no. 6, pp. 2531-2540.

34. Pauly C., Spring P., O'Doherty J.V., Ampuero Kragten S., Bee G. Growth performance, carcass characteristics and meat quality of group-penned surgically castrated, immunocastrated (Improvac () ) and entire male pigs and individually penned entire male pigs. Animal, 2009, vol 3, pp. 1057-1066.

35. Severiano S., Alfredo T., Font i Furnols M. A handbook of reference methods for meat quality assessment. European Cooperation in Science and Technology, Action FA1102, Farm Animal Imaging. Edinburgh: SRUC; 2015. DOI: 10.13140/RG.2.1.3379.2481

36. Skrlep M., Segula B., Zajec M., Kastelic M., Kosorok S., Fazarinc G., Candek-Potokar M. Effect of immunocastration (Improvac®) in fattening pigs. II: Carcass traits and meat quality. Slovenian Veterinary Research, 2010, vol 47, pp. 65-72.

\section{References:}

1. Antipova L.V., Zubairova L.A., Danyliv M.M., 2006. Census qualitas et salus cibum products [Evaluation of quality and safety of meat products]. Omnes fere cibum, № 1, pp 8-9.

2. Bazhov G., Bakhireva L., 2004. Methodi biotechnologici ad augendam fructibus porcorum [Biotechnological methods to increase the productivity of pigs]. Sus fetura, № 3, pp. 6-9.

3. Bambulyak N.F., Vylkov S.G., Roibu R.I., 1990. Influentia dosed activitatem motoriam in parametris morphometricis brachii et ocrearum porcorum [Influence of dosed motor activity on morphometric parameters of forearm and shin bones of pigs]. Eget ac diam facies morphologiam pet. Sat. scientificum. tr. KSKHI. Cishinev, pp.41- 44.

4. Bankovskaya I.B., 2008. Influentia geneticae aspectus intensiva pastio in suilla qualitatis [Influence of genetic aspects of intensive fattening on pork quality]. Tauriana Scientia Newsletter: zb. scientiarum. Ave KHDAU. Kherson: Aylant, Vip. 58. Part 2. pp. $108-112$.

5. Bankovskaya I.B., 2013. Influentia ad gignendum, pondus ac genus musculorum viventium in cadaverum porcorum qualitate maturationis [Influence of factors of breed, live weight and type of muscles on the quality of maturation of pig carcasses]. Materias xx Mezhdunar. scientific-practical conf. porcus fetura, Problemata moderna et innovationes technologicae in productione Вісник Сумського національного аграрного університету 
suilla in CIS terries, XX Intern. scientific-practical conf. fetura porcus, Cheboksary, 20-21 lunii, pp. 150-156.

6. Bankovskaya I.B., 2014. Celeri aestimatio musculi dynamici generis maturationis in cadaveribus sus [Rapid assessment of dynamic-type muscle maturation in pig carcasses]. Sat. Acta Mezhdunar. scientific-practical conf., Competitiveness et qualitas products, Colloquium scientificum practicum internationale, die 18 -19 septembris, pp. 308-310.

7. Bankovskaya I.B., 2016. Amino acid compositio suillae diversorum generum et condicionum pondere [Amino acid composition of pork of different breeds and weight conditions]. Collectio materiarum interretialis colloquii scientifico-practici All-Ucraini, Status et spes gregum in Ucraina progressionem current, All-Ucraina colloquium scientificum-practicum interretialem in Kherson, die 8 Septembris, pp. 83-86.

8. Bankovskaya I.B., 2017. Substantiation and development of a system for evaluation, forecasting and optimization of production of quality pig products. Auctoris ref. Diss, theologus. S.-g. scientiarum.

9. Birta G.O., Burgu Yu. G., Floka L.V., 2019. Compositio morphologica de cadaveribus porcinis diversorum genera. Porci prolem. [online] no. 73. Available at: <http://nbuv.gov.ua.UJRN.svun> [Accessed 22.08.2021].

10. Birta G.O., Burgu Yu.G., 2011. Merx merx scientia [Meat commodity science]. Kyiv: Centrum Litterarum Litterarum.

11. Bulatovich O.M., 1999. Productio et quaedam biologica porcorum genotyporum diversa [Productivity and some biological features of pigs of different genotypes]. Bulletin of Science №5, pp. 76-77.

12. Burgu Yu.G., 2005. Suspendisse suavitate nobilissimas porcelli et crossbred [Stress sensitivity of purebred and crossbred piglets]. Sus prolem. № 1, pp. 8-9.

13. Pondus V.N., 1990. Caro qualitas in porcos hybrid [Meat quality in hybrid pigs]. Sus prolem. 1990. Part. 46, pp. 35-38.

14. Esca et Carnes producta. Methodi determinationis pinguium GOST 23042-86. [Valida ex 1988-01-01. Receptum 201207-30]. Moscoviae: USSR publicae Committee pro signis.

15. Bankovskaya I.B., 2010. Aestimatio conductivitatis electrica musculi suici texti genotyporum diversorum [Evaluation of electrical conductivity of pig muscle tissue of different genotypes]. Sus fetura: interdepartmental. argumento. Scientia. zb. Poltava, issue 3, pp. 40-46.

16. Pavlovsky P.V., Palmin V.V., 1975. Biochemistry carnium [Biochemistry of meat]. Moscoviae: Cibus Industry, pp. 234 239 .

17. Pat. N. 88937, Ucraina, IPC A $01 \mathrm{~K}$ 67.02. Modus determinandi cadaverum porcorum qualitatem carnium. Bankovska I. B., Voloshchuk V.M., Ivanov V.O. No. u 201311251; app. 09/23/2013; publ. 04/10/2014; Bui. N. VII.

18. Plokhinsky N. A., 1969. Directiones biometricae ad pecorum specialitas [Biometrics guide for livestock technicians]. Moscuae: Kolos, pp. 256.

19. Svechin Yu, O., Galkina L.O.,1990. De qualitate carnium generosorum et crossbredorum porcorum [About the quality of meat of purebred and crossbred pigs]. Sus prolem. № 5, pp. 26. №. 2 , pp. 4 .

20. Stepanov V., Fedorov V., Tarichenko A., 1998. Fetura porcorum ad escam [Pig breeding for meat content]. Sus prolem.

21. Sheiko I.P., Epishko T.I., Gridyushko I.F., Gridyushko E.S., 2005. Usus DNA technologiae determinans vim sentiendi vimque porcorum [The use of DNA technology in determining the stress sensitivity and productivity of pigs]. Vesci Nationalis Academiae Scientiarum Belarus, Scientiae Agrariae Gray. №3, pp. 76-78.

22. Shipulin V. I., 2006. Qualitas crudae carnium et problematum eius processus [The quality of raw meat and the problems of its processing]. Nomenclator SevKavGTU, №1 (5), pp. 15-18.

23. Auqui, S. M., Egea M., Peñaranda I., Garrido M. D., Linares, M. B., 2019. Rustic Chato Murciano pig breed: Effect of the weight on carcass and meat quality. Meat Science. pp. 105-110. doi:10.1016/j.meatsci.2019.05.022.

24. Cronin G.M., Dunshea F.R., Butler K.L., McCauley I., Barnett J.L., Hemsworth P.H., 2003. The effects of immuno- and surgical castration on the behaviour and consequently growth of group-housed, male finisher pigs. Applied Animal Behaviour Science 81, pp.111-126.

25. D'Souza D.N., Mullan B.P., 2002. The effect of genotype, sex and management strategy on the eating quality of pork. Meat Science, № 60, pp. 95-101.

26. Eugeniusz Ryszard Grela, Małgorzata Świątkiewicz, Edyta Kowalczuk-Vasilev Mariusz Florek, 2019. An attempt of implementation of immunocastration in swine production - impact on meat physicochemical quality and boar taint compound concentration in the meat of two native pig breeds. Livestock Scienceю, №232(1). doi:10.1016/j.livsci.2019.103905.

27. Grau R, Hamm R., 1953. Eine einfache methode zur bestimmung der wasserbindung inmuskel. Naturwissenschaften. № 40 pp. 29-30 doi.org/10.1007/BF00595734

28. International Organization for Standardization, 1999. ISO 2917:1999. Meat and meat products. Measurement of pH. Reference method. Geneva, Switzerland: ISO.

29. International Organization for Standardization, 1991. ISO 3100:1. Meat and meat products. Sampling and preparation of test samples. Geneva, Switzerland: ISO.

30. International Organization for Standardization, 2005. ISO 5983-1:2005. Feeding stuffs - Determination of nitrogen content and calculation of crude protein content - Part 1: Kjeldahl ( $\mathrm{N}$ x 6.25)., Geneva, Switzerland: ISO.

31. Lundstrom K., Matthews K.R., Haugen J.E., 2009. Pig meat quality from entire males. Animal, № 3, pp. 1497-1507.

32. Marina Gispert, Maria Angels Oliver, Antonio Velarde, paloma suarez Suarez., 2010 Carcass and meat quality characte istics of immunocastrated male, surgically castrated male, entire male and female pigs. Meat Science, №85(4), pp. 664-700. doi:10.1016/i.meatsci.2010.03.021

33. Nayara Andreo, Ana Maria Bridi, Caio Abércio da Silva, Louise Manha Peres, Barbara de Lima Giangareli, Évelyn 
Rangel dos Santos, Camila Piechnicki Roge, Jéssica Gonçalves Vero, Guilherme Agostinis Ferreira, 2018. Immunocastration and its effects on carcass and meat traits of male pigs. Semina: Ciências Agrárias, vol. 39, no. 6, pp. 2531-2540.

34. Pauly C., Spring P., O'Doherty J.V., Ampuero Kragten S., Bee G., 2009. Growth performance, carcass characteristics and meat quality of group-penned surgically castrated, immunocastrated (Improvac®) and entire male pigs and individually penned entire male pigs. Animal, vol 3, pp. 1057-1066.

35. Severiano S., Alfredo T., Font i Furnols M., 2015. A handbook of reference methods for meat quality assessment. European Cooperation in Science and Technology, Action FA1102, Farm Animal Imaging. Edinburgh: SRUC. doi: 10.13140/RG.2.1.3379.2481

36. Skrlep M., Segula B., Zajec M., Kastelic M., Kosorok S., Fazarinc G., Candek-Potokar M., 2010. Effect of immun?castration (Improvac®) in fattening pigs. II: Carcass traits and meat quality. Slovenian Veterinary Research, vol 47, pp. 65-72.

Andreeva Diana Nikolaevna, graduate student, Nikolaev National Agrarian University (Nikolaev, Ukraine)

Influence of gilts immune castration and their pre-slaughter live weight on meat quality indicators

The article compared the physicochemical parameters and the chemical composition of the longest back muscle (m. Longissimus dorsi) in immunocastrated and non-castrated gilts obtained from hybrid sows of the Irish Landrace and Irish Yorkshire and boars of the synthetic line Maxgro after their slaughter in $110 \mathrm{~kg}$ and $130 \mathrm{~kg}$. It was found that there were no significant disagreements in the physical and chemical parameters of the meat of immunocastrated and non-castrated gilts of both studied weight categories. However, there was a tendency to an increase in the percentage of free moisture in the meat of immunocastrated animals after 48 hours and on the 6th day after slaughter, the water-holding capacity, the content of bound moisture in\% to the total moisture and marbling in comparison with their non-castrated counterparts. At the same time, in terms of color and electrical conductivity after 48 hours and on the 6th day after slaughter, non-castrated gilts with live pre-slaughter weight of $110 \mathrm{~kg}$ had an advantage over their counterparts, while animals in the $130 \mathrm{~kg}$ weight category showed an opposite trend in terms of the studied indicators. From the analysis of active acidity indicator of the longissimus dorsi muscle, it was found that the maturation of muscle tissue in immunocastrated gilts in both weight categories was somewhat slower than in non-castrated gilts. With an increase in the pre-slaughter live weight from 110 to $130 \mathrm{~kg}$, the meat of both immunocastrated and non-castrated gilts gained more acidic reaction. According to the chemical composition of the longissimus dorsi muscle, significant differences between immunocastrated and non-castrated animals with different pre-slaughter live weight were not installed, and all the studied parameters were within the normal range for meat of the NORM category. According to the indicators of the mass fraction of moisture and ash, there was a tendency to their increase in the meat of immunocastrated gilts with a pre-slaughter live weight of $110 \mathrm{~kg}$ by $0.15 \%$ and $0.02 \%$, and with a pre-slaughter live weight of $130 \mathrm{~kg}$, respectively, by $0.20 \%$ and $0.01 \%$ compared to their non-castrated counterparts. It was determined that a large mass fraction of protein was in the meat of non-castrated gilts with a pre-slaughter live weight of 110 and $130 \mathrm{~kg}$, respectively, by $0.21 \%$ and $0.18 \%$ compared to immunocastrated animals of the same weight categories. The mass fraction of fat in the muscle tissue of immunocastrated gilts with a live weight of $110 \mathrm{~kg}$ was higher by $0.04 \%$ in comparison with the meat of their non-castrated counterparts. At the same time, with a weight category of $130 \mathrm{~kg}$ in the longissimus dorsi muscle of immunocastrated pigs, the mass fraction of fat was $0.03 \%$ less than in non-castrated animals of the same weight category. According to the results of two-factor analysis of variance, the effect of the factor of the pre-slaughter live weight of animals, the type of castration and their interaction did not have a statistically significant effect on most of the studied physicochemical parameters, which in most cases depended on unaccounted factors. The obtained research results showed that the use of immune castration for gilts did not have a negative effect on the quality indicators of gilts' meat.

Keywords: pig, immune castration, slaughter live weight, meat quality, chemical indicators, free water, water-holding ability, active acidity, electrical conductivity

Дата надходження до редакції: 08.09.2021 p. 